\title{
In vitro toxicity of indoor fungi from dwellings in Slovakia: testing on the isolated lung cells
}

\author{
Z. Kováčiková ${ }^{,}$, E. Tátrai ${ }^{2}$, E. Piecková ${ }^{1}, Z$. Kolláriková ${ }^{1}$, \\ V. Jančinováa ${ }^{3}$, J. Tulinská ${ }^{1}$, M. Kuricová ${ }^{1} \&$ A. Líšková ${ }^{1}$ \\ ${ }^{1}$ Slovak Medical University, Bratislava, Slovakia \\ ${ }^{2}$ NIEH, Budapest, Hungary \\ ${ }^{3}$ Institute of Experimental Pharmacology SASc, Bratislava, Slovakia
}

\begin{abstract}
The lung is the target organ of multiple aggressions due to environmental noxious substances, indoor pollution, occupational hazards and personal risk such as cigarette smoke. Metabolites produced by different fungus species can also be present the inhaled air. Their effects are not frequently studied in the lung or in the lung cells. Our study focused on the effects of metabolites (both exoand endometabolites) produced by Aspergillus ustus, Aspergillus versicolor, Penicillium chrysogenum and Stachybotrys chartarum isolated from dwellings in Slovakia. Their effects were studied in vitro on alveolar macrophages and epithelial type II cells isolated from Wistar rats and Clara cells isolated from mice. Alveolar macrophages represent a free living population in the alveolar spaces and play an important role in maintaining clean and sterile alveoli; they contribute also to the production of proinflammatory cytokines. Epithelial type II cells play a critical role in preserving the functional integrity of the alveolar surface and they also produce cytokines. The effects of metabolites were evaluated by estimating their cytotoxicity, the activity of lysosomal enzyme acid phosphatase in alveolar macrophages. Lectins were used for studying the changes on cell surface. The production of cytokines (Monocyte Chemoatractant Protein 1- MCP-1 and Tumor Necrosis Factor $\alpha-$ TNF- $\alpha$ ) was also measured. The effects of metabolites were dose dependent, the highest toxicity was evoked by Stachybotrys chartarum metabolites.
\end{abstract}

Keywords: indoor fungi, lung cells, metabolites, in vitro. 


\section{Introduction}

As to the cell types, the lung is a very heterogenous organ: it consists of more than 40 different cell types [1]. The large surface of the lung (in man about the size of a tennis court) is exposed to air on the epithelial side. Each cell type has a unique morphologic characteristic associated with its function. The greatest interest in pulmonary toxicology is focused on alveolar macrophages, type II alveolar epithelial cells and non-ciliated bronchiolar Clara cells. Alveolar macrophages (AM) represent a free living cell population in the alveolar spaces and account for $5 \%$ of peripheral lung cells. They come in a direct contact with toxic particles and gases as well as pathogens contained in the inspired air, they are essential to the maintenance of clean and sterile alveoli. The alveolar epithelial surface is built up of two distinct epithelial cell types, type I and type II. Type II cover approximately $5 \%$ of the alveolar surface area and play a critical role in preserving the functional integrity of the alveolar surface. They contain significant amounts of drug biotransformation enzymes, can replicate and play an important role in tissues renewal, they are also progenitors of type I cells and synthetize surfactant. The bronchial epithelium contains at least 8 cell types, one of them are toxicological important Clara cells. They are highly metabolic active in bronchiolar region, serve as progenitor for themselves and bronchiolar ciliated cells and secrete various products to the bronchiolar lining fluid which help maintain the lung healthy. Isolation of individual cell types from lung and their culture with different toxic agents gives the possibility for better understanding of the cell response.

Occupants of moldy buildings often report health problems, they may be caused by exposure to microbes [2]. Still it is not known which components of the microbial flora belong to the most harmful. In the presented study we tested the effects of metabolites produced by different fungal isolates from moldy buildings in Slovakia on isolated lung cells in in vitro culture.

\section{Materials and methods}

Scheme of experiment Alveolar macrophages (AM) and type II cell were isolated from rats $[3,4]$ and Clara cells were isolated from mice [5]. The isolated cells were cultivated under standard laboratory condition in Dulbecco's Modified Eagles Medium (DMEM) with 5\% fetal bovine serum (FBS) for 20 hours in the atmosphere of $5 \%$ carbon dioxide in air at $37^{\circ}$. Medium was replaced by fresh medium with $5 \%$ FBS and with various concentration $(0,1-5 \mu \mathrm{g} / \mathrm{ml})$ of different metabolites produced by fungal isolates and the cultivation continued for another 24 hours. After finishing the cultivation medium was withdrawn and used for cytotoxicity testing and measuring the concentration of cytokines (MCP-1 and TNF- $\alpha$ ). Cells were washed twice with phosphate buffered saline and the staining with lectin (Maclura pomifera - MCA) was performed on type II cells and the acid phosphatase activity was determined in AM.

The metabolites from Aspergillus ustus, Aspergillus versicolor, Penicillium chrysogenum and Stachybotrys chartarum were used. The isolation of produced 
metabolites from culture medium of fungi - exometabolites and from the mycelium - endometabolites was done by the standard procedure [6].

The cytotoxicity was evaluated by ToxiLight BioAssay Kit (Cambrex, UK) in the cultivation medium. The kit is based on the bioluminescent measurement of adenylate kinase which is present after cell damage in the cultivation medium. The luminescence was measured in a microtitre plate computer-driven luminometer Immunotech LM-01T (Immunotech, Czech Republic).

Lectin histochemistry. Maclura pomifera agglutinin (MPA) staining was performed according McBride et al [7].

Proinflammatory cytokines analysis. Concentration of proinflammatory cytokines Monocyte Chemoatractant Protein 1 (MCP-1) and Tumor Necrosis Factor $\alpha$ (TNF- $\alpha)$ in medium from AM and type II cells cultivation was determined using sandwich ELISA procedures. The procedure was provided according to respective kit instruction (BD Biosciences) and final absorbances were read at $450 \mathrm{~nm}$ using the microplate reader.

\section{Results}

The cytotoxic effect of metabolites produced by different fungi was estimated in the cell culture medium after $24 \mathrm{~h}$ culture period of alveolar macrophages, epithelial type II cells and Clara cells. The effect of metabolites isolated from the culture medium of fungi (exometabolites) is shown in Figure 1 and the effect of metabolites isolated from the mycelium (endometabolites) is in Figure 2. In all experiments the concentration of metabolites was $2 \mu \mathrm{g} / \mathrm{ml}$.

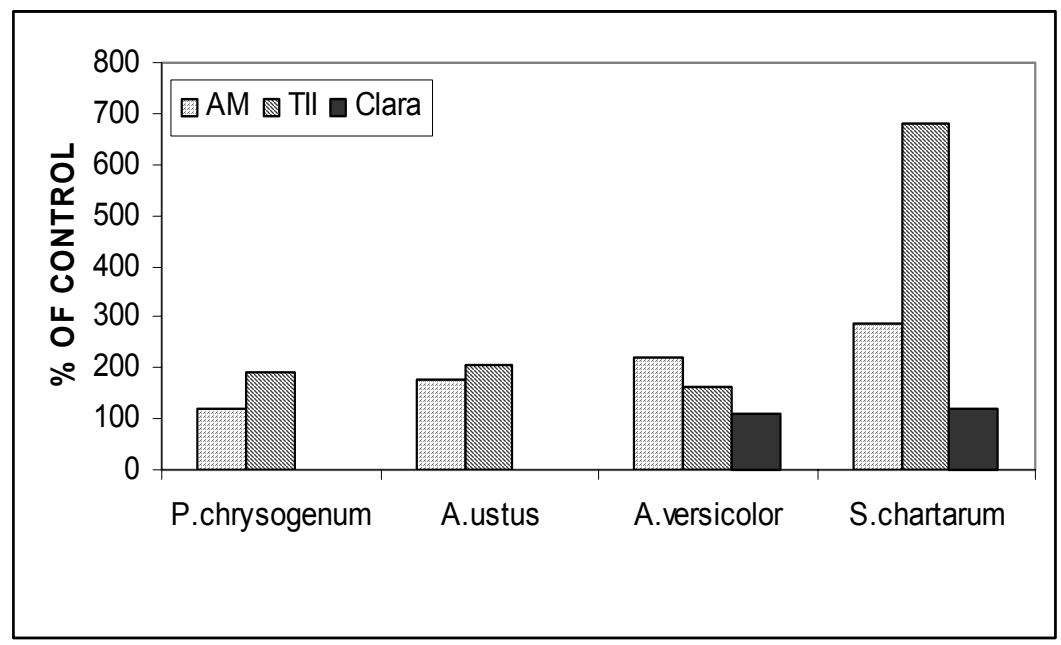

Figure 1: The cytotoxic effect of $2 \mu \mathrm{g} / \mathrm{ml}$ exometabolites of different fungi on cultured cells isolated from lung.

MCP-1 and TNF- $\alpha$ were estimated only in the medium after $24 \mathrm{~h}$ period of culture with metabolites of Stachybotrys chartarum. TNF- $\alpha$ concentration in the 
medium from AM culture showed strongly metabolite concentration depend enhancement, while MCP-1 production both by AM and TII cells decreased in dose dependent manner.

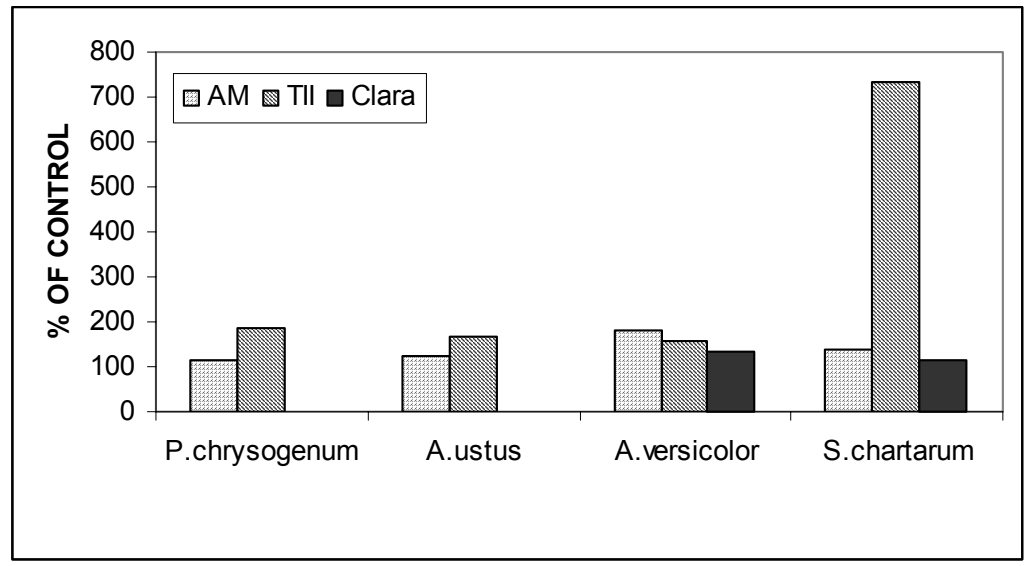

Figure 2: $\quad$ The cytotoxic effect of $2 \mu \mathrm{g} / \mathrm{ml}$ endometabolites of different fungi on cultured cells isolated from lung.

The activity of acid phosphatase in AM was measured after $24 \mathrm{~h}$ culture with metabolites. The effects evoked by $2 \mu \mathrm{g} / \mathrm{ml}$ of different metabolites are summarized in Figure 3. The activity was decreased in all cases except the exometabolites of A. versicolor but at higher concentration also these metabolites caused already a strong inhibition of the acid phosphatase activity.

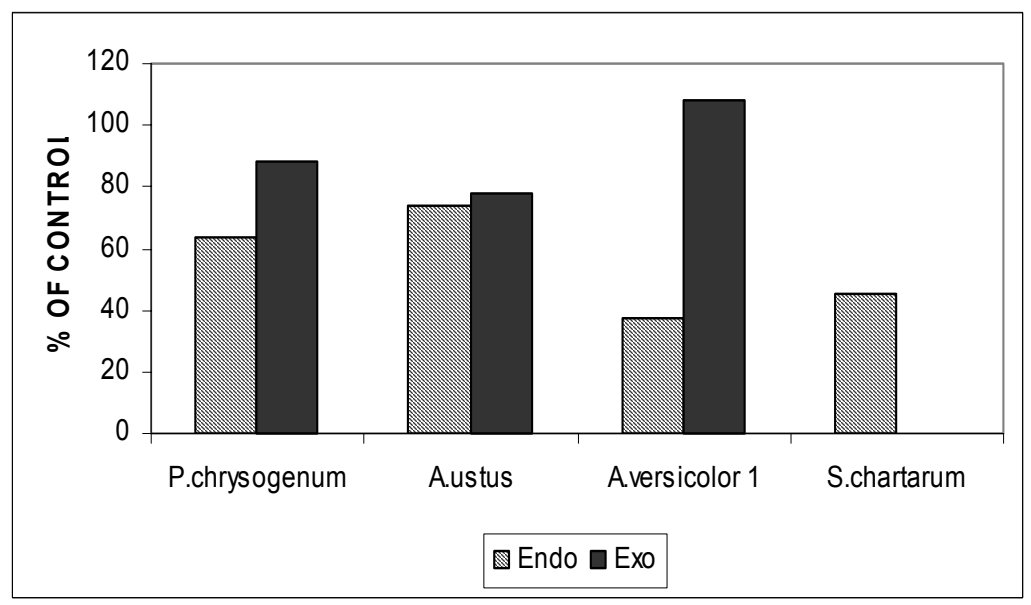

Figure 3: $\quad$ Effect of $2 \mu \mathrm{g} / \mathrm{ml}$ of endo- and exometabolites isolated from fungi on the activity of acid phosphatase in alveolar macrophages after $24 \mathrm{~h}$ in vitro culture. 
The binding activity of MPA was followed in TII cells. The control cells showed positive staining of membranes (Figure 4) whilst the staining of cells cultured with metabolites revealed fragmentation of the membranes.

The effect of exometabolites produced by A. versicolor in concentration 2 $\mu \mathrm{g} / \mathrm{ml}$ is demonstrated in Figure 5 .

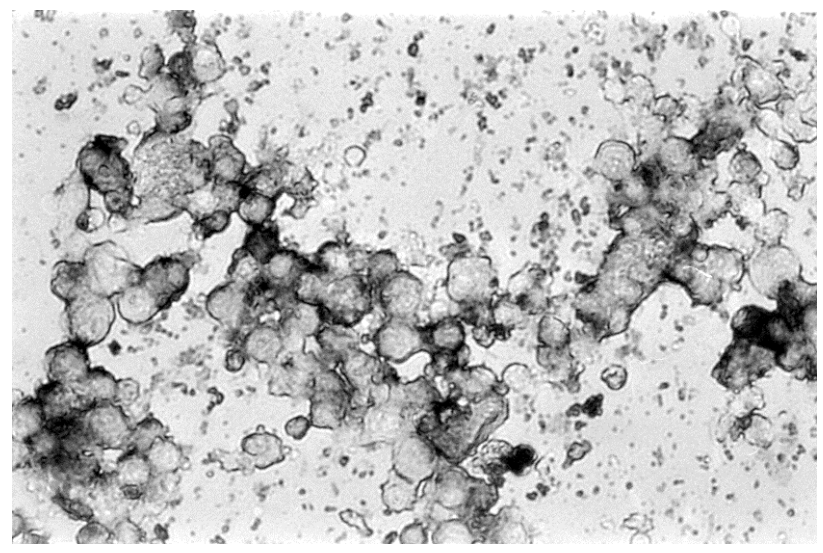

Figure 4: Cultured rat type II cells - staining with MPA, magnification: x320.

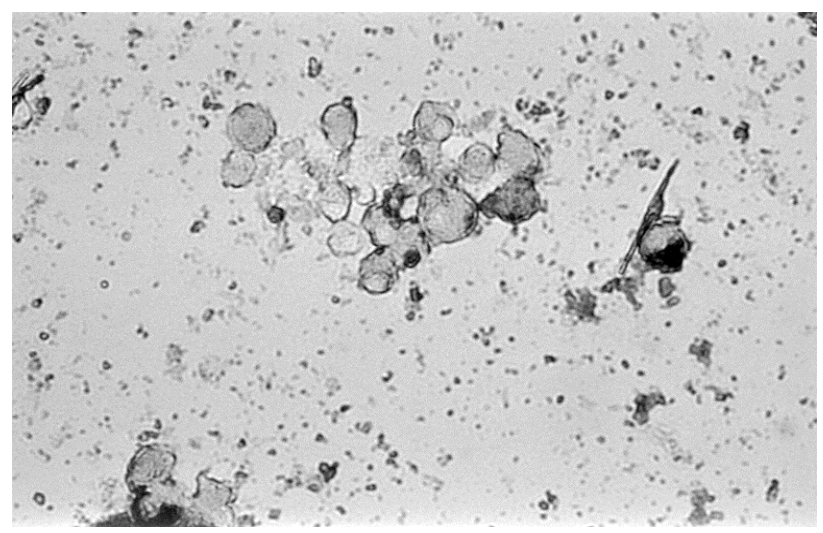

Figure 5: Cultured rat type II cells after $24 \mathrm{~h}$ exposure to $2 \mu \mathrm{g} / \mathrm{ml}$ exometabolites of $A$. versicolor - staining with MPA, magnification: $\mathrm{x} 320$.

\section{Discussion}

Papers in the literature which deal with the effects of indoor mold can be divided into those dealing with spores $[8,9]$, with the metabolites produced by the fungi [10] or both spores and metabolites [11]. 
The aim of this study was to gain some insight into the effects of metabolites produced by different fungal isolates on target cells isolated from lung. The fungal isolates represent a mixture of metabolites which act probably synergistically $[12,13]$. Four various tests were used: measuring the cytotoxic effect, estimation of cytokines to show the inflammatory potential of metabolites, the binding ability of MPA on type II cells and estimation of acid phosphatase activity in AM. Changes in MPA binding revealed changes in the plasma membranes of type II cells. The nature of MPA interaction with specific carbohydrate (glactose or N-acetylgalactosamine) is potentially useful marker of early epithelial changes in lung disease [14]. Alveolar macrophages are rich in lysosomal enzymes, including acid phosphatase. The enzymes are released after ingestion of foreign material into cytoplasm or even into the external environment [15]. All tested metabolites showed toxic effects, the sensitivity of individual cell types was different. Evaluating and comparing the results will be done by cluster analysis.

The same metabolites as in presented paper were tested in their ability to break down ciliary beating in tracheal epithelium in the organ culture [16]. The toxic effect was observed at the concentration $20 \mu \mathrm{l} / \mathrm{mg}$. In our experiments this concentration caused complete destruction of type II cells (unpublished results).

Our previous study was focused on comparing the effects of metabolites isolated from four different strains of Stachybotrys chartarum [17] in vitro. The results showed that metabolites from all strains were toxic and they differ only in extent of the evoked changes.

Huttunen et al [8] studied and compared the inflammatory and cytotoxic responses caused by household mold in lung cell lines and accordingly the results concluded that inflammation might be the primary response in the lung. We detected both cytotoxic and inflammatory effects of isolated metabolites produces by fungi but in this state of knowledge we cannot proclaim what was the primary response.

\section{Acknowledgements}

The study was supported by the Ministry of Health of the Slovak Republic under the project 2005/36-SZU-14 and by EC contract HEAR NAS QLK6-2002-90945.

\section{References}

[1] Sorokin, S.P., Properties of alveolar cells and tissues that strengthen alveolar defences. Archives of Internal Medicine 126, pp.450-463, 1970.

[2] Peat, J.K., Dickerson, J., Li, J., Effects of damp and mould in the home on respiratory health: a review of the literature. Allergy 53, pp.120-128, 1998.

[3] Myrvik, Q.N., Leake, E.S., Farris, B., Studies on pulmonary alveolar macrophages from the normal rabbit: A technique to procure them in a high state of purity. Journal of Immunology 86, pp.128-132, 1961. 
[4] Richards, R., J., Davies, N., Atkins, J., Oreffo, V.I.C., Isolation, biochemical characterisation and culture of lung type II cells of the rat. Lung 165, pp.143-158, 1987.

[5] Oreffo, V.I.C., Morgan, A., Richards, R.J., Isolation of Clara cells from the mouse lung. Environmental Health Perspectives 85, pp.51-64, 1990.

[6] Kováčiková, Z., Piecková, E., Tátrai, E., Pivovarová, Z., Mataušic-Pišl, M., Use of the in vitro model for the evaluation of toxic effects of metabolites produced by fungi. Environmental Health Risk IV., Ed. C.A.Brebbia, pp79-84, 2000

[7] McBride, S., Tátrai, E., Blundell, R., Kováčiková, Z., Cardozzo, L., Adamis, Z., Smith, T., Harrison, D., Characterisation of lectin binding patterns of mouse bronchiolar and rat alveolar epithelial cells in culture. The Histochemical Journal 32, pp.33-40, 2000.

[8] Huttunen, K., Hyvärinen, A., Nevalainen, A., Komulainen, H., Hirvonen, M.R., Production of inflammatory mediators by indoor air bacteria and fungal spores in mouse and human cell lines. Environmental health Perspectives 111, pp.85-92, 2003.

[9] Becher, R., Rakkestad, K.E., Holme, J.A., Rydjorg, B., Hetland, G., Hongslo, J.K., Schwarze, P.E., Effects of two different fungal spores types often found in moisture-damaged buildings on cytokine production and apoptosis in alveolar rat macrophages. Toxicology and Applied Pharmacology 197, pp. 303-304, 2004

[10] Nielsen, K.F., Huttunen, K., Hyvarinen, A., Andersen, B., Jarvis, B.B., Hirvonen, M.R., Metabolite profiles of Stachybotrys isolates from waterdamaged buidings and their induction of inflammatory mediators and cytotoxicity in macrophages. Mycopathologia 154, pp.201-205, 2002.

[11] Mason, C.D., Rand, T.G., Oulton, M., MacDonald, J.M., Scott, J.E.,

[12] Effects of Stachybotrys chartarum (atra) conidia and isolated toxin on lung surfactant production and homeostasis. Natural Toxins 6, pp.27-33, 1998

[13] Andersson, M.A., Nikulin, M., Koljalg, U., Andersson, M.C., Rainey, F., Reijula, K., Hintikka, E.L., Salkinoja-Salonen, M., Bacteria, molds, and toxins in water-damaged building materials. Applied and Environmental Microbiology 63, pp.387-393, 1997

[14] Koshinsky, H., Khachatourians, G., Trichothecene synergism, additivity, and antagonism: The significance of the maximally quiescent ratio. Natural Toxins 1, pp. 38-47, 1992

[15] Kasper, M., Schuh, D., Muller, M., Bauhinia purpurea lectin (BPA) binding of rat type I pneumocytes: Alveolar epithelial alterations after radiationinduced lung injury. Experimental and Toxicologic Pathology 46, pp.361367, 1994.

[16] Brain, J.D., Mechanism, measurement and significance of lung macrophage function. Environmental Health Perspectives 97, pp.5-10, 1992.

[17] Piecková, E., Kolláriková, Z., In vitro toxicity of indoor moulds from Slovak dwellings. Environmental Toxicology (in press).. 
218 Environmental Toxicology II

[18] Kováčiková, Z., Tátrai, E., Piecková, E., Tulinská, J., Pivovarová, Z., Mataušic-Pišl, M., Kuricová, M., Wsolová, L., An in vitro study of the toxic effects of Stachybotrys chartarum metabolites on lung cells. ATLA 35, pp. 147-52, 2007. 